\title{
PRIMATE CENSUS IN KATHMANDU AND WEST PARTS OF NEPAL
}

\author{
M. K. Chalise
}

\begin{abstract}
Nepal consists of three major monkey species in different phytoecological zones from Tarai plain to the valleys of high mountains. This paper includes the census data, available for three species of monkeys of Nepal obtained from different research activities.
\end{abstract}

Key words: Census, distribution, Nepal monkey, population

\section{Introduction}

Primates are censused in some parts of Nepal during different research activities. A detail list of previous years has been published recently (Chalise 2006). The information gathered here are some of the data collected and compiled recently from some areas of Nepal. Some of the areas are new for the scientific studies.

\section{Materials and Methods}

The areas with primate availability reported and noticed were selected as "focal area." Such focal areas were visited on foot and the individual counting was repeated several times in one observation assisted by binocular. Cross counting were also done by the researchers to come into most reliability of the population number. The counting was done continuously thoroughly in each observed group by scan sampling methods (Martin and Bateson 1993) by the help of binoculars and cameras as per need.

\section{Results}

The author with the help of his assistants has done census of monkeys in different parts of Nepal. Some major sites of monkey census are presented below with age sex division and other scattered census data are also presented in the tabular form (Table-1).

Kathmandu Monkeys: (27 34'N-27 48' 185 10'E-85 32'E)

Recent census of Shivapuri area revealed that there are at least 120 rhesus monkeys in 6 different troops (Bashyal, 2005, Nepal, 2005).

Langtang National park: (85 15'-86 0'E / 28 20'N)

Langtang National Park is located in the central Himalayan region of Nepal and located $132.2 \mathrm{~km}$ north of Capital City Kathmandu and in the northeast bordering to the Nepal-Tibet, autonomous region of China. Langtang area is focused in primate survey due to its availability of three species in different altitudinal ranges. The censuses were carried out not only during the specific primate survey project but also during other projects such as snow leopard study in upper reaches of park. To trek up to upper reaches the vegetation zones and primate habitats were to cross at least for 2 full days. During those period researchers were collecting 
population data of primate species too.

During the census period of July and August of 2006, at lest 62 Langurs were counted from 4 different troops of Bokajhunda - Sole, Trishuli bridge, Sebrubeshi - Dovan and Bamboo area 1545 to $1980 \mathrm{~m}$ above the sea level associated with other references too (Table- 1 ). The total number indicates the male population seems higher and immature are less. However, due to topographical obstacles and shy nature of monkeys may not allow counting infant completely, though mature numbers are adequately trustworthy.

During the same period Assamese monkeys were counted in higher number totaling 148 individuals from 6 different troops inhabiting in the steep slope mountain forest of 1500 to 1700 meter above the see level (Table-1). These monkeys are found basically along the Trishuli river basin and in a very accessible area such as Ghattekhola of Dhunche and Chilime bridge of Sebrubeshi.

Similarly, during a trip (2007 February) for snow leopard study a ten days field work was undertaken and few days were spent to observe primate species. Only Langur species were observed and counted at least 68 individuals from 4 different troops from the elevation of 1800 meter to 2200 meter.

\section{Dhading District of Central Nepal}

Along the Trishuli River and its tributaries a survey of Assamese monkeys were during November and December of 2006. Troop ranging from 12 to 27 individuals were observed in 5 troops and total count was 78 individuals of different age and sex. Local people reported that during the hot season and calamities these monkeys are capable of crossing the Trishuli River on either side.

\section{Beg Khola, Myagdi}

A troop of bisexual Assamese monkeys were observed with 20 individuals of different age across the Kali River on the slope of the mountains. They were eating petioles of Khirra leaf.

\section{Kopche Pani, Myagdi}

A troop of 12 Hanuman Langurs were observed with 2 adult male and 4 adult females with juveniles and infants above the tea shops' slope. They were eating Kaulo type leaf and licking greenish rock.

\section{Palpa: (27 34'N-27 58' I 83 15'E-84 22'E)}

Matin danda: Palpa is a mid-hill district of west Nepal lying south of Kaligandaki River at 152 to $1936 \mathrm{~m}$ asl. The study of Rhesus monkey was initiated in 2000 on rhesus monkeys of Bandipokhara area (Ghimire, 2000). Recent census (2004) around the Matindanda village in a community forest revealed a total of 67 rhesus monkeys were counted in three troops. Similarly, northern parts of this VDC, there are 40 rhesus monkeys in a bisexual troop of different age around the government forest of Ghiunsibas village, Brangdi VDC and 25 monkeys counted recently at the south bank of KaliGandaki River in Phanta, Khanigaun VDC. A famous Rani Mahal area, Baugha Gumba VDC in the bank of same river, a very shy troop of Hanuman Langurs was noticed but count was incomplete. Ramdi Area (27?45' N, 
83? 55' E) is small highway settlement in Palpa District along the Kali Gandaki River. It is contagious with the temperate forest to the north and subtropical hill Sal forest (Shorea robusta) and riparian forest in the south. Elevations are quite low (around $420 \mathrm{~m}$ asl), however, due to the areas location in the mid hill's mountains in central Nepal, running east to west along the Himalayas, and lying north of the Churiya range of Nepal, floristically it shows an affinity with the Palearctic. It is accessible by road transportation and Assamese monkeys are easily observed waiting along the highway. We counted 30 individuals of different age and sex.

\section{Discussion}

The non-human primates in different parts of Nepal are not thoroughly observed and censused. The information is patchy accordance to the research sites and author's census. The Biodiversity Profile Project initiated the collection of information; however, it relayed mostly on the secondary data and less concerned with available previous literatures. It could not trace out the primate research already completed in Nepal around 80s and 90s. Including the previous census (Chalise 2006) and Table -1 , altogether $1966(1714+252)$ rhesus monkeys, $816(686+130)$ Langur monkeys and $734(482+252)$ Assamese monkeys were counted. The later census was mostly from the mid-hills and higher mountain valleys. The census availed data shows that primate species are common in the wilder areas of Nepal and monkeys inhabit close to human settlements and crop field. Such regular findings also indicate that continuous census should be done to establish scientific status of monkeys in Nepal and to acquire basic distribution pattern and availability of the species.

\section{Acknowledgments}

I thank to my students Mr. Suvas C. Ghimire, Janak R. Khatiwada, Ganga Ram Regmi, Purna Ale, Reshmi R. Bashyal and Hari K. Nepal for their assistance during the population census. International Primatological Society, IPS and American Society of Primatologists, ASP for the small grant support. Dr. Randall C. Kyes is thankful for his continuous support and collaboration for the scientific study and conservation thrust of wildlife of Nepal specially primates.

\section{Reference}

Bashyal, R.R (2005). Study of Population and Feeding Ecology of Rhesus Monkey (Macaca mulatta) in Shivapuri National Park, Kathmandu, Nepal. M.Sc. Thesis, Central Department of Zoology, Kirtipur, TU., Nepal.

Chalise M. K. (2006). Primate census in different parts of Nepal. Journal of the University Campus TUTA, TU, Prospective on Higher Education. 2 \& 3: 35-41.

Ghimire, S.C (2000). Study of Rhesus monkeys (Macaca mulatta) of Bandipokhara VDC Area, Palpa Nepal. M.Sc. Thesis, Central Department of Zoology, Kirtipur, TU., Nepal.

Martin P. and Bateson P. (1993). Measuring behaviour. Cambridge University Press, NY, USA.

Nepal, H.K. (2005). Habitat utilization and conflict with people of Rhesus monkey (Macaca mulatta) in Shivapuri National Park. , Central Department of Zoology, Kirtipur, T.U. Nepal. 
Rhesus Surney in 2004

Table- I

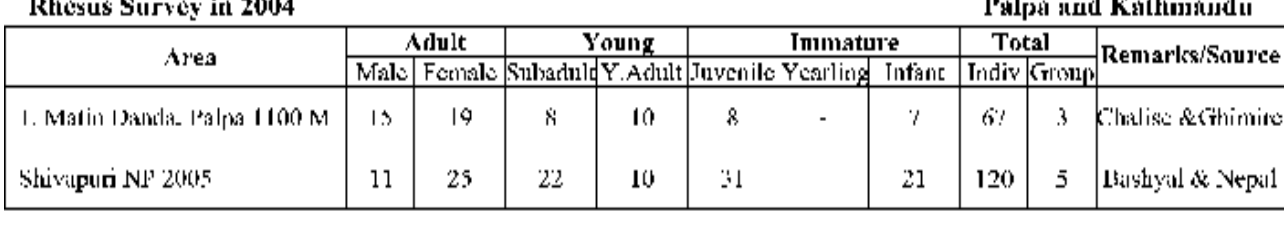

Aknurrene Sirrey in 2004

I.Anglarig $\mathrm{NP}$

\begin{tabular}{|c|c|c|c|c|c|c|c|c|}
\hline \multicolumn{9}{|l|}{ 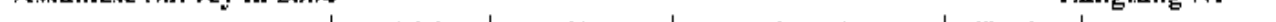 } \\
\hline \multirow{2}{*}{ Aren } & \multicolumn{2}{|c|}{ Andult } & \multirow{2}{*}{$\frac{\text { Youns }}{\text { SubududtY.Adult }}$} & \multicolumn{2}{|c|}{ Immature } & \multicolumn{2}{|c|}{ 'T'utıl } & \multirow{2}{*}{ Renthlkstsusec } \\
\hline & Milse & Fome & & Juvenjle Y Yeutling & lntianc & Indix: & coroup & \\
\hline Pahil't II (2000ي May') & 2 & 11 & $5(\mathrm{Bix})$ & & 8 & 26 & I & IR Khationata \\
\hline
\end{tabular}

2005 Oquber (Census by Resini Raj Raghyal) (T.lectria l.rop killed 4 rhesus in Khanigan 2062) Palpa

\begin{tabular}{|c|c|c|c|c|c|c|c|c|c|}
\hline \multirow[b]{2}{*}{ Areil } & \multicolumn{2}{|c|}{ Antult } & \multicolumn{2}{|c|}{\begin{tabular}{|c|} 
Youns \\
\end{tabular}} & \multicolumn{2}{|c|}{ Immature } & \multicolumn{2}{|c|}{ 'T'utill } & \multirow{2}{*}{ Koniltks/sourec } \\
\hline & Whalk & l. intutle & Subudu] & Y.Adult & Jnwenjle fearling & $\ln f_{i l n}$ & Indik: & Group & \\
\hline I. Ghiunsibas, Rarangdi. Palpa & 2 & 9 & 6 & 7 & 8 & 8 & 40 & I & $5 \mathrm{~K} / \mathrm{mN}$ of Tansen \\
\hline 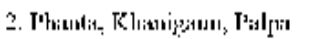 & । & 5 & 4 & 5 & 6 & 1 & 2.5 & I & $9 K_{\text {TIIN }}$ \\
\hline
\end{tabular}

Lingur

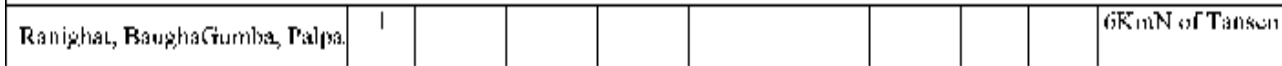

\begin{tabular}{|c|c|c|c|c|c|c|c|c|c|}
\hline \multicolumn{6}{|l|}{ Assamege biprey in 20106 July A ngust. } & \multicolumn{4}{|c|}{ I sangtang VP andi Its Buffer rome } \\
\hline Alct & & kiult & $\mathbf{Y}$ & rutuger & 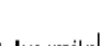 & Imontururs: & T'vt & till & Ritmirks \\
\hline 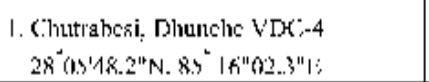 & 3 & 7 & 5 & - & 3 & 4 & 22 & 1 & $\begin{array}{l}\text { Kolatiwada, } \\
\text { Rogntri antil }\end{array}$ \\
\hline 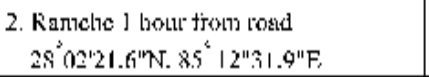 & 4 & $\eta$ & 3 & - & 2 & 7 & 25 & 1 & 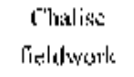 \\
\hline 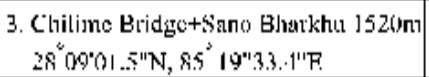 & 4 & 7 & 6 & & 4 & 6 & 27 & I & \\
\hline 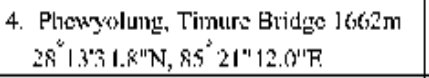 & $\mathbf{I}$ & - & - & - & - & - & $\mathbf{I}$ & Alone & \\
\hline 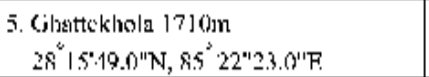 & $\mathbf{I}$ & - & - & - & - & - & $\mathbf{I}$ & Alone & \\
\hline 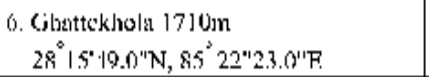 & 8 & II & 4 & & 5 & 7 & .35 & I & $1,1,1-3$ \\
\hline 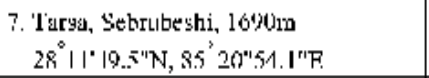 & 3 & 7 & 3 & & 4 & 4 & 21 & 1 & pllying will \\
\hline 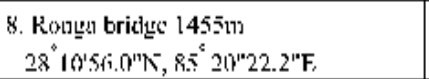 & .3 & 5 & 2 & & .3 & 3 & 16 & 1 & \\
\hline 'Intal & 27 & 46 & 23 & - & 21 & 31 & $14 \beta$ & 6 & \\
\hline
\end{tabular}




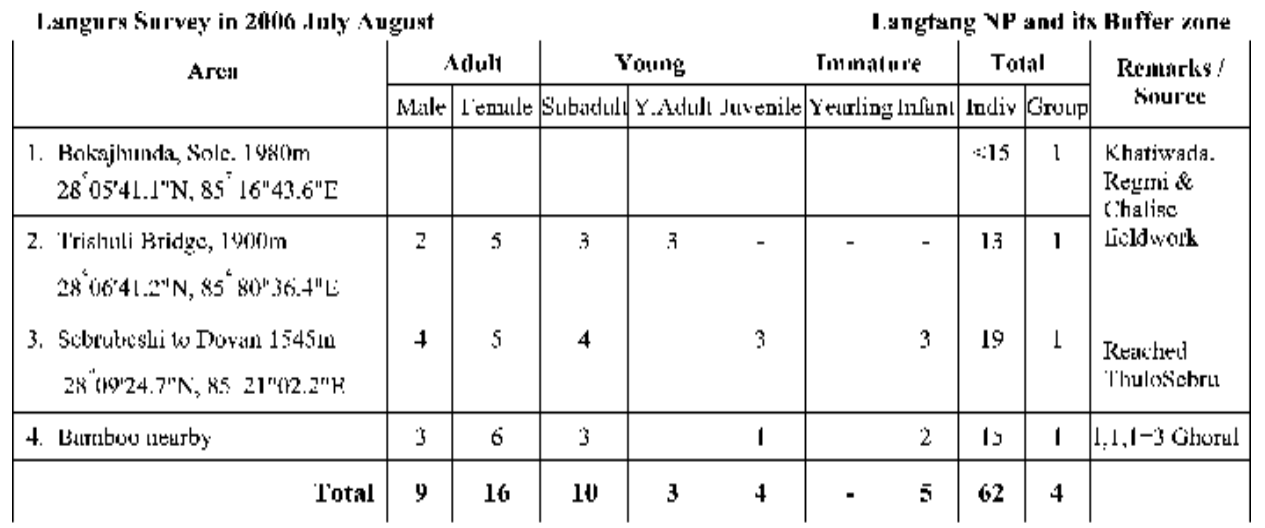

Assamese surtey 2006 Nov December

Dhadieg Distrifet

\begin{tabular}{|c|c|c|c|c|c|c|}
\hline \multirow{2}{*}{ Areat } & \multicolumn{2}{|c|}{ Ad ull. } & \multirow{2}{*}{$\frac{\text { Yòutḩ }}{\text { ל่ub-பdult }}$} & \multicolumn{2}{|c|}{ Imwhit uret } & \multirow[t]{2}{*}{ Tolal } \\
\hline & Mul: & l'imuls: & & Juvinnid: & اתמל:كון & \\
\hline 1. Kint:ang & 2 & 4 & 3 & 1 & 3 & 13 \\
\hline 2. kigau & 3 & 4 & 2 & $\mathbf{1}$ & 2 & 12 \\
\hline 3. Joģimiara & 6 & 9 & 4 & 3 & 4 & 26 \\
\hline 4. Near Fisling MKC & 4 & 8 & 5 & 6 & 4 & 27 \\
\hline Total & 15 & 25 & 14 & | | | & 13 & 78 \\
\hline
\end{tabular}

Primate silurvey in 2 anit lichrmary

I Angurs

\begin{tabular}{|c|c|c|c|c|c|c|c|c|c|}
\hline \multirow{2}{*}{$\begin{array}{c}\text { Ares } \\
\text { L angtam gu Nutionul Park }\end{array}$} & \multicolumn{2}{|r|}{ Adult } & Youmy & \multicolumn{3}{|c|}{ Inımature } & \multicolumn{2}{|r|}{ Intal } & \multirow[t]{2}{*}{ Rtmurl's / Silu rce } \\
\hline & Muls & $\therefore \sin u \mid$ & Subatult & I uvenils & 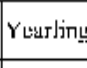 & Iת|'แ⿰亻⿻乚 & | & Ciтnup & \\
\hline 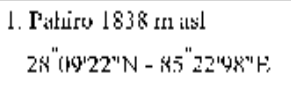 & 3 & 5 & & 5 & & 1 & 14 & 1 & 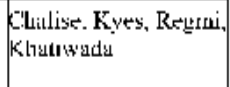 \\
\hline 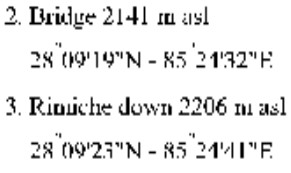 & 6 & 13 & & 2 & & 2 & 20 & 1 & 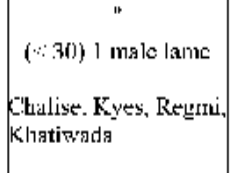 \\
\hline 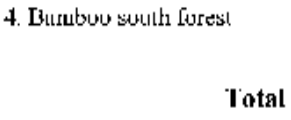 & $\begin{array}{l}2 \\
17\end{array}$ & $\begin{array}{l}5 \\
35\end{array}$ & & 12 & & $\begin{array}{l}1 \\
4\end{array}$ & $\begin{array}{r}8 \\
68\end{array}$ & $\begin{array}{l}1 \\
4\end{array}$ & 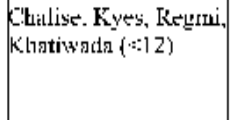 \\
\hline
\end{tabular}

Kanchanpur Nagarjun Buffer zone Com. forest, Rhesus 15, Arjuni phanta 10, Majhagaun 15, Langur $10-2007$ April

\section{Author's Address}

Dr. Mukesh Kumar Chalise

Central Department of Zoology, TU, Kathmandu

Submitted Date: October 18, 2007

Email: nebors@ccsl.com.np

Accepted Date: May 8, 2008 